\title{
RUNNING AWAY FROM CHILDREN'S RESIDENTIAL CARE: THE FINNISH CASE
}

\section{Susanna Hoikkala and Martti Kemppainen}

\begin{abstract}
This article discusses the phenomenon of running away from children's residential care in the Finnish context. In the Finnish welfare system, residential care is understood as a last-resort form of alternative care. Its aim is to secure children's well-being, development, and safety. Our article is based on the findings of a small-scale study launched and administrated by the Central Union for Child Welfare. These findings illustrate the multidimensional nature of the topic. First, the reasons for and the consequences of running away are diverse. Second, we need implementation of more inclusive and consistent practices as well as more explicit cooperation between authorities. Finally, the importance of children's peer relations should be taken more seriously within residential care services. In this article, these findings are discussed bearing in mind the following critical question: What is the point of child welfare if it fails to serve children and safeguard their well-being and health during the out-of-home placement?
\end{abstract}

Keywords: running away, residential care, professional practices

Susanna Hoikkala is a Senior Advisor at the Central Union for Child Welfare, Armfeltintie 1, 00150 Helsinki, Finland. E-mail: susanna.hoikkala@lskl.fi

Martti Kemppainen is a Senior Advisor at the Central Union for Child Welfare, Armfeltintie 1, 00150 Helsinki, Finland. E-mail: martti.kemppainen@lskl.fi 
In Finland, running away from residential care is a well-known phenomenon within the field of child welfare, but one that has been little examined. In recent years, it has become a matter of concern in the field that knowledge regarding child welfare in general and children's alternative care in particular is limited and fragmented (e.g., Pekkarinen, 2011). The extent and nature of running-away behaviour, as well as professional interventions and responses to it, have not been adequately explored and problematized (Central Union for Child Welfare [CUCW], 2013, pp. 4-5).

This article is based on a small-scale study launched and administered by the Central Union for Child Welfare (CUCW) in 2012 and 2013 ${ }^{1}$. In the Finnish context, the need for this particular study emerged from many sources. The topic was first discussed with several partner organizations of $\mathrm{CUCW}^{2}$ when the Police Board of Finland was renewing national guidelines concerning cooperation between the police and child welfare practitioners in 2011. At the same time, grassroots level practitioners expressed concerns about the well-being of young runaways because of the serious dangers into which their flights often lead them. Also, those health services workers identified running away as a risk for children's health and well-being; children's uncontrolled sexual behaviour was considered especially alarming. In addition, absconding was considered to threaten the placement process by disrupting the children's regular lives (see also Fasulo, Cross, Mosley, \& Leavey, 2002, p. 624). Running away was also recognized as a burden to the service system, because the necessary response involves numerous resources and multiple authorities. The lack of knowledge and appropriate know-how was the final starting point. These background observations are in many ways similar to the findings of international research on the topic (e.g., Biehal \& Wade, 2000; Fasulo et al., 2002; Malloch \& Burgess, 2011).

Contemporary researchers use the terms "running away" and "runaways" to refer to children in a variety of situations, not just residential care. For Biehal and Wade (2000, p. 213) "going missing" includes all types of unauthorized absences from placement, covering both children gone missing overnight and children reported as "missing" to the police. Malloch and Burgess (2011) use the alternative terms "absconding" and "absconders". Those studies, however, cover incidents of running away both from familial homes and from various child welfare services. This article discusses a study restricted to children under the age of 18 who were taken into care via a care order and placed in residential care units ${ }^{3}$. The cases of children who run away from their familial homes and foster homes were not examined. The Finnish equivalents of the phrases "running away" and "on the run" are used widely, and these terms also have slang equivalents. In the study considered here, the term "unauthorized absence" refers to incidents in which a child has either left the residential care unit without permission or has not returned at the agreed time. "Running away" is used, however, almost as a synonym. These terms are therefore used interchangeably in this article, as well as the terms "absconding" and "flight". In the Finnish context, "going missing" refers mainly to a case that has been formally reported to the police as a "missing person". Child welfare cases are rarely reported in that way.

The study had several practical objectives. First, it aimed to locate some of the main features of running away as a phenomenon; and to gather information on the frequency of flights, on models of cooperation between different authorities, and on existing good practices. A second aim was to find out the judicial status of the child and the child's rights during the unauthorized absence. Third, the study attempted to map a course for both policy and practice, and to make concrete recommendations for further actions. This article focuses mainly on the first and third objectives.

\section{Children's Residential Care in Finland}

In Finland, the welfare system is based on a Nordic welfare state model: universal welfare, extensive statutory services, and a shared value base with a strong emphasis on social solidarity, on equal rights, and on access to basic services. The child welfare system has also been built upon 
these cornerstones. Policies regulating the position of children and families with children have traditionally been considered first-class in the Nordic countries (e.g., Eydal \& Satka, 2006).

Challenges to the system have emerged in the past few years, however, in the form of neoliberal ideas and market-oriented values based on new public management as well as privatization of services (e.g., Forsberg \& Kröger, 2011, pp. 1-2; Satka, Harrikari, Hoikkala, \& Pekkarinen, 2007). These new ways of thinking have become more prevalent in many areas, including the field of children's alternative care. For instance, the organization of service provision has become more market-oriented: the number of private and even commercialized for-profit service providers has mushroomed, and the practice of "shopping around" to get "the best value" for the money available has become more usual (e.g., Eronen, Laakso, \& Pösö, 2011). Many municipalities have decreased their own service provision and instead purchase welfare services, including child welfare, from NGOs and private enterprises.

In Finland, the objective of the Child Welfare Act (Lastensuojelulaki 417/2007, section 1) is to protect children's rights to a safe growth environment, to balanced and well-rounded development, and to special protection. It emphasizes the principles of the child's best interest, children's and families' participation in child welfare decisions, and alternative care as a last-resort and a temporary solution. The act does not allow permanent placements of children and, in principle, the primary aim is always family reunification. However, this is not possible in every case and, therefore, long-term placements do exist. In Finland, adoption is not used as a child welfare measure and parents do not lose their parental rights.

The need for child welfare services has tripled in Finland since the early 1990s. In 2012, the number of children using child welfare and social work services was 87,200 . Altogether 17,830 children were in out-of-home placements during that year, this number included both existing and new placements, short-term as well as long-term. Therefore, approximately $1.4 \%$ of children under 18 years of age were in out-of-home placements. The number of children taken into care has remained nearly the same in recent years, but the number of children placed outside their homes has continued to grow. The number of children who were taken into care or placed urgently for the first time was 3,079 in 2012; of these, 2,726 were placed urgently. The growth in the number of teenagers in need of urgent or other out-of-home placement stands out. Slightly more boys than girls are placed in alternative care (Child Welfare 2012, 2013).

There are any many ways to implement alternative care: foster care, professional foster families, residential care (such as reception centres, children's homes, youth homes, and reform schools), and other care, such as independent living. The described services are provided by the state (in six reform schools), the municipalities, NGOs, and private enterprises. In Finland, residential care units are open, except for a few that operate as special care units for short placement periods. That kind of care and treatment is arranged by a multiprofessional team and the placement period requires a special care order by a municipal office-holder. Special care may be arranged for children aged 12 years or more to stop them from engaging in behaviours that seriously harm them. Continual absconding may be handled in this way. The length of a placement may be to a maximum of 90 days, and includes restricting the child's freedom of movement. Special care units are small, handling a maximum of five children at a time, with a high ratio of staff to children. Intensive dialogue between the staff members and the children is emphasized. The main aim is to get a child to settle down and to enable a change in the child's situation (see Pösö, Kitinoja, \& Kekoni, 2010).

In international comparisons, Finland is usually categorized as placing an emphasis on residential care services for children rather than foster care (e.g., Eronen et al., 2011). In recent years, however, many initiatives have been introduced to strengthen foster care, including the 
revision of child welfare legislation in 2012. At the regulatory level, this revision prioritized foster care as the primary form of alternative care in Finland for the first time. According to the Child Welfare Act (Lastensuojelulaki 417/2007), "institutional care is arranged if substitute care for the child cannot be provided in the best interest of the child in family care or elsewhere by means of sufficient supportive measures" (section 50). At the end of 2012, 50\% of children placed out-ofhome were in foster care, $18 \%$ in professional family homes, $27 \%$ in residential care, and $4 \%$ in other forms of care (Child Welfare 2012, 2013).

Numerous factors and the cumulative effect of simultaneous ongoing difficulties can lead to an out-of-home placement. They include challenges faced by parents, such as difficulty in coping with everyday life, inadequate parenting skills, substance abuse, and mental health problems. On the other hand, some issues can be related to the child's own behaviour and psychological wellbeing, such as self-endangerment by substance abuse. A child may have serious difficulties at school or problems with inappropriate friendships. A child's absconding from a familial home can be the main reason for a placement, but in such cases children only enter alternative care when they have run away repeatedly (see Heino, 2007; Myllärniemi, 2006). Heinonen, Väisänen, and Hipp (2014) discuss the ways in which a child can become a child welfare client and the various paths a child may take through the Finnish child welfare services.

\section{Running Away from Alternative Care}

As mentioned above, we do not have much research-based information about running away from alternative care in Finland, even though this phenomenon is well known among practitioners and mentioned in some studies (e.g., Hoikkala, 2011; Pekkarinen, 2010; Vehkalahti \& Hoikkala, 2013). Only one publication, Saari's Karkailun ongelma [The Problem of Runaways] ${ }^{4}$, published in 1965, focuses particularly on this topic in the context of children's residential care. It consists of four different studies carried out in reform schools from 1946 to 1955. The number of running-away incidents varied annually during that time. The autumn months seemed to be the most popular for absconding, with Sunday the preferred day; more than half of the cases did not last longer than a week, and running away presumed "readiness and a trigger" (Saari, 1965, pp. 43-44). The explanations offered for running away mainly invoked the individual characteristics of the runaways and their familial conditions, but also the "environmental conditions" of the reform schools. Saari posed an important question: What is the reason for boys feeling forced to escape from their living conditions? He concluded that the flight may be motivated either by a rejection or by a "tropism" (Saari, 1965, pp. 44-45).

These observations from almost half a century ago remain pertinent to the present day: there remain many ways to explain running away and of defining the runaway child. As discussed in other studies, responses to the topic and ways of intervening in individual cases reflect the surrounding societal context (see, e.g., Biehal \& Wade, 2000; Malloch \& Burgess, 2011.) Within Finnish child welfare praxis, running away is generally understood as a threat to the child's growth and well-being, because the child's safety may be at risk during the unauthorized absence (CUCW, 2013, p. 5). A runaway child may be characterized as being “in need”, or "troublesome”, or both. Child flights inspire feelings that range from concern and despair to frustration and even anger. However, interventions with runaways should always be based on welfare principles instead of the impulse to punish with sanctions such as prolonged confinement. Restrictions, including restriction of freedom of movement, may be used after a flight but they should only be used as defined in the Child Welfare Act (Lastensuojelulaki 417/2007) and after applying a thorough case-specific consideration and a formal decision-making procedure.

In Finland, there is no appropriate statistical data available for illuminating the extent of running away. A similar observation is made in many foreign studies as well (e.g., Biehal \& Wade, 
2000, p. 214; Malloch \& Burgess, 2011, p. 64). Incidents of running away are recorded in children’s individual case files, but residential care units are not required to compile statistics or to report the number of cases to monitoring authorities or any other bodies in a systematic way. If a child runs away or does not return to the unit on time, the residential care workers must report the situation at least to the child's social worker or to emergency social services, and to the legal custodian(s). The social worker with jurisdiction is obliged to report the case to the police and to request executive assistance for locating and returning the runaway. However, not all runaways are reported to the police specifically as missing children. Variations in the procedures used for reporting a missing child and requesting police assistance may result in differences in the official status of a runaway child. It seems that the police do not maintain systematic records of all cases in which their assistance is requested by social workers on behalf of missing children. Therefore, the police records are not comprehensive enough to illuminate the extent of running away nationally.

\section{The Study}

The Central Union for Child Welfare launched a study on unauthorized absences of young people from residential care and practices of residential care units in autumn, 2012. This study is descriptive rather than explanatory by nature. The data, collected by two external researchers, included a web-based questionnaire as well as five interviews. Seven young people with personal experience of residential-care placement were interviewed in a group. Three social workers from the municipal child-welfare social work units and one social worker from the municipal emergency social services were interviewed via email. The group interview was transcribed and analysed using the methods of content analysis (CUCW, 2013).

The questionnaire asked the respondents to provide basic background information on the residential unit and the educational background of the managers and the caregivers ${ }^{6}$, as well as statistical information on the frequency of running away. Information was gathered on the key features of runs; for example, why children run away, what happens during a run, how children are brought back and what brings them back, as well as interventions after a run. The respondents were asked to identify the number of running-away incidents and individuals during the last one-month and six-month periods (see also Biehal \& Wade, 2000, p. 214). In addition, they were asked to provide information on local protocols and to describe good practices.

The questionnaire was distributed to 413 children's residential care units ${ }^{7}$. Altogether 81 responses were received ${ }^{8}$ from reform schools (5), municipal reception centres (9), private units (44), municipal units (17), and other units (4). Most of the responses were received from the southern part of Finland. The data provided by the questionnaires were analysed by calculating the responses and by evaluating the content of open questions.

\section{Findings}

Respondents reported that 306 children had running-away incidents, lasting for a total of 2,996 days. The total number of children who had repeated runaways during the previous six months was 184 (14.7\% of all beds in residential units, $n=1251)$. As one would expect, there are some children who run off repeatedly, and others who do so only once or twice. One third of the runaways had been placed with an emergency care order and two thirds with a standard care order. Sixteen incidents took place while under an order of special care (Lastensuojelulaki 417/2007, section 71).

Thirteen units reported that they had not had any incidents of running away during the time. About $46 \%$ of the respondents indicated that running away had not increased during the past year (CUCW, 2013, p. 18). 
Differences between genders varied during the previous month compared to the six-month period. There were more female than male runaways during the month: 50 girls and 38 boys had run away, making the total number 88. During the longer period, there was no difference: 153 girls and 153 boys had run away during the previous six months. The length of placement of the runaways varied between one month and 190 months.

The duration of flights ranged from less than 24 hours to 185 days. The average duration was eight days. In Finland, there is no official distinction between a "temporary" run and a "permanent" run, even though some municipalities do not pay to the service provider the total care fee after a certain period of absconding (e.g., the fee may be cut to half after seven days of running away). In the study by Fasulo et al. (2002, p. 628), a duration of less than two weeks distinguished a temporary run from a permanent one.

The responses in the questionnaires revealed that most of the unauthorized absences had started from within a residential unit: a child had absconded from the unit without permission. Most children left alone, but in some cases a group "escape” occurred (see also Biehal \& Wade, 2000). The rest referred to cases in which a child had not returned to the unit from holidays as agreed. Responders indicated that some children had run away for the excitement of it and "just for fun", while others had planned their flight carefully. It can be argued that children with such different motivations are seeking different things when they run away. The impulsive runaway may require different management than a child who has made a careful plan to stay away for an extended time. This variability poses an additional challenge to the service system.

Most often, the young runaways were found in their community of origin or the town or municipality nearest to the residential care unit. More than half of them were among their friends. Some children were found in a public place such as a city centre or a street. There were also children who were with their family members or relatives. Most often, children run away to their family of origin or to their friends.

According to this study, children return to the residential unit most often either by themselves or with staff members who have been searching for them. A child can also be returned by the police or by a family member (CUCW, 2013, p. 34).

\section{During the flight}

Incidents that occurred while a child was "on the run" included misuse of alcohol and drugs, involvement in offending, violence (child's own behaviour), trading sex for money or substances, self-harming, pressure for sexual contact, abuse, and even rape (CUCW, 2013, p. 33). These findings are similar to many other studies. For example, Courtney et al. (2005) state that many runaways are exposed to sexual and criminal victimization and are at risk of abusing drugs and alcohol or committing crimes themselves. In this study, $65 \%$ of the respondents indicated that unauthorized absence is occasionally a serious risk for the child's growth and development, and $29 \%$ estimated it to be always a serious risk.

\section{Why do children run away?}

The respondents indicated that the main motivations for unauthorized absences were related to friends and peer relations, because runaways wanted to spend time with their friends (see also Biehal \& Wade, 2000, p. 217). For some, the escape meant a quest for freedom. Misuse of substances can be the main motivation for some children, or the desire to escape the restrictive 
nature of the residential care unit and to test boundaries. In some responses, the psychological condition (distress and poor coping mechanisms) and behavioural problems of a child were defined as key factors. Family-related issues were reported to be important too: children want to run to their biological parents, siblings, and relatives for a number of reasons. In some cases, disagreements or conflicts between a child and either staff members or other children in the unit were considered the main motivations (CUCW, 2013, p. 19).

Biehal and Wade (2000, p. 218) talk about "pull factors" and "push factors" when discussing the reasons for running away. This categorization is present in this study also. Some issues are clearly related to the world outside the residential unit, such as those involving peer relations, girlfriends and boyfriends, or conflicts with parents. Some are closely related to internal matters and to features of residential care as such, like conflicts with staff members. Some childrelated reasons for running away include misuse of substances, boredom, and anxiety. Institutionrelated reasons such as seeking to avoid rules, regulations, and sanctions can be defined as push factors.

Young people who were interviewed emphasized several motivations for running away, including (a) factors outside a residential unit: friends, family, a girlfriend or boyfriend, hanging around, partying; (b) factors related to their well-being: substances, boredom, anxiety; (c) factors related to the institution: rules and regulations, unwillingness to live in the institution, disagreements with the staff or with other children; (d) impulses: "just wanted to do it"; and (e) lack of freedom. They indicated that children in general and their distress in particular should be taken more seriously in residential care (CUCW, 2013, p. 22-23).

The respondents were also asked to suggest key factors that could be linked to running away in general. The most common factor mentioned was the child's objection to the placement: the child had objected to alternative care. In addition, it was felt that children in the teenage years were more likely to run away than those younger. The third reason commonly advanced was parental objection to the placement. The last two causes may be related to insufficient preparation for the process of placement and a mismatch between the needs of the child and the residential care unit (CUCW, 2013, p. 22).

\section{After running away}

A runaway child's uncertain emotional and physical condition, including the possibility of abuse and neglect, demand sensitivity of the workers in their interventions. In this study, most of the respondents indicated that a warm, emphatic, and caring welcome after the flight is crucial. Children should be given positive feedback for returning. The basic needs of the child, such as food, sleep, and hygiene, should be met first. After an appropriate time, a report of the events needs to be made with the child. In some cases, the report is completed by the child and the worker of the residential care unit; in others, family members and the social worker responsible for the child are involved. It is crucial to find out what caused the flight, to learn what took place while the child was unsupervised, and to determine what should happen afterwards (CUCW, 2013, pp. 34-35).

In some cases, procedures such as bodily search, drug testing, and restrictions of contacts and freedom of movement were applied. Health checks made by a medical doctor were also used. The respondents emphasized that restrictions and procedures were instituted only for the well-being of the child, not as punishments (CUCW, 2013, p. 35).

The flights could have both short-term and long-term consequences. In extreme cases, a change of placement location was decided upon. For some children, this meant a period at the 
special care unit, and for some a treatment period in a mental health unit, such as a psychiatric ward for adolescents (CUCW, 2013, pp. 36-37).

\section{How to prevent running away}

This study found that clear policies and practices are very important as preventive factors. There should be both multi-agency protocols and locally-defined guidelines. In this study, about 6\% of the respondents did not have any local written protocols on running away (CUCW, 2013, p. 24). Residential care units may have a lot of working knowledge of the topic, but it is not made visible. Local practices and the position of the social worker as a part of the process should be clarified. Some respondents claimed that they lack the resources to eliminate absconding. However, respondents were confident in being able to mount an immediate response when a child has run away: to start a search, and to contact the child's family (CUCW, 2013, pp. 25-28).

The study revealed that the nation-wide guidelines are unclear and are inconsistently applied. This raises an issue of children's rights, as children are likely to be treated differently in different parts of the country. When a child runs away, cooperation between the front-line workers in residential care, the social worker responsible for the child's placement, the police, the emergency social services, and the emergency response centre is needed. However, this study revealed gaps and grey areas both in the cooperation between authorities and in their responsibilities. These administrative boundaries between various authorities must be bridged in the future. The authors of this study propose that the national guidelines should be improved, as should the level of cooperation among various authorities (CUCW, 2013, pp. 11-13).

\section{Sensitive situations need sensitive reactions}

This study indicates that children who run away need understanding rather than punitive reactions and restrictions. Appropriate means for surveillance and preventing escapes are required. The findings suggest that children should be given more time with workers and that the workers should pay more attention to building mutual trust. Communication between the children and the professionals should be increased and improved.

One sensitive reaction worth mentioning is the need to recognize the importance of family members, friends, and others close to the child. Taking these crucial relationships more seriously could foster the child's commitment to the process. Dealing with peer and other social relations can be challenging in the context of residential care. On the one hand, troubled peer relations can be a reason for the child's placement and the need for alternative care. On the other hand, children's peer relations should be supported to maintain their right to access and relationships. In the future, we suggest the following questions should be explored: how should "good" and "bad" peer relations be defined, and how should friends best be involved in the everyday lives of the children (CUCW, 2013, p. 20).

Our final comment concerns children who run away repeatedly and do not settle down into any kind of alternative-care unit. These children may go from placement to placement in different units with little prospect of stability. Such cases present a challenge for the service system for many reasons. Children who have experienced many placements probably do not have a trusting relationship with care workers, and may not respond as hoped to interventions. The Finnish view of child welfare is that children cannot be locked up and their movement restrained for a long time. Sometimes it is difficult to settle a child down without such measures. Once a cycle of unstable and unsuccessful placements is under way, child welfare practitioners may not have other tools to break it. The well-being of the children may be difficult to secure in these circumstances. We must ask 
how better to meet the needs of children whose multiple attempts at running away disrupt their prospects for an ordinary life. This question should be elaborated and explored further in future research.

\section{Conclusion}

In this article we have introduced a study on unauthorized absences from children's residential care, implemented by the Central Union for Child Welfare in Finland, and discussed its main findings. First, the reasons for running away, as well as its consequences, are diverse. Second, there is a need for the implementation of more inclusive and consistent practices as well as more explicit cooperation between authorities. Finally, the importance of peer relations to children within residential care services should be recognized.

We also want to draw attention to the importance of appropriate placement procedures. It seems that running away is closely tied to the success of the whole process. Children and their needs should be assessed properly and carefully matched to an alternative care unit (Pösö \& Laakso, 2014). This applies not only at the individual level but also at the level of policy. Social workers must ensure that children are placed appropriately and that their particular needs are met. 


\section{References}

Biehal, N. \& Wade, J. (2000). Going missing from residential and foster care: Linking biographies and contexts. British Journal of Social Work, 30(2), 211-225. http://dx.doi.org/10.1093/bjsw/30.2.211

Child Welfare 2012. (2013). Statistical Report 30/2013. Helsinki, Finland: National Institute for Health and Welfare. Retrieved from http://www.julkari.fi/handle/10024/110691

Courtney, M., Skyles, A., Miranda, G., Zinn, A., Howard, E., \& Goerge, R. (2005). Youth who run away from substitute care. Chapin Hall Working Paper. Chicago, United States: Chapin Hall Center for Children at the University of Chicago. Retrieved from http://www.chapinhall.org/sites/default/files/old_reports/174.pdf

Central Union for Child Welfare. (2013). Hatkassa: Selvitys nuorten luvattomista poissaoloista ja sijaishuoltopaikkojen toimintakäytännöistä [On the run: A study on unauthorized absences of young people and practices of alternative care units]. Helsinki, Finland: Central Union for Child Welfare.

Eronen, T., Laakso, R., \& Pösö, T. (2011). Now you see them - now you don't: Institutions in child protection policy. In H. Forsberg \& T. Kröger (Eds.), Social work and child welfare politics. Throuqh Nordic lenses (pp. 147-159). Bristol, United Kingdom: The Policy Press. http://dx.doi.org/10.1332/policypress/9781847424068.003.0010

Eydal, G. B., \& Satka, M. (2006). Social work and Nordic welfare policies for children - present challenges in the light of the past. European Journal of Social Work, 9(3), 305-322. http://dx.doi.org/10.1080/13691450600828358

Fasulo, S., Cross, T., Mosley, P., \& Leavey, J. (2002). Adolescent runaway behavior on specialized foster care. Children and Youth Services Review, 24(8), 623-640. http://dx.doi.org/10.1016/s0190-7409(02)00211-6

Forsberg, H., \& Kröger, T. (2011). Introduction. In H. Forsberg \& T. Kröger (Eds.), Social work and child welfare politics. Through Nordic lenses (pp. 1-9). Bristol, United Kingdom: The Policy Press. http://dx.doi.org/10.1332/policypress/9781847424068.003.0001

Heino, T. (2007). Keitä ovat uudet lastensuojelun asiakkaat? Tutkimus lapsista ja perheistä tilastolukujen takana [Who are the new clients of child welfare? A study of the children and families behind the statistics]. Helsinki, Finland: Stakes, Työpapereita 30.

Heinonen, H., Väisänen, A., \& Hipp, T. (2014). How child welfare costs accumulate? Helsinki, Finland: Central Union for Child Welfare.

Hoikkala, S. (2011). Ratsauksia ja kusitestejä. Päihde- ja huumekontrolli lastensuojelulaitoksessa. [Raids and urine tests. The control of substance abuse in children's residential care.] In M. Satka, L. Alanen, T. Harrikari, \& Elina Pekkarinen (Eds.), Lapset, nuoret ja muuttuva hallinta [Children, youth and transforming governance.] (pp. 243-278). Tampere, Finland: Vastapaino.

Lastensuojelulaki 417/2007. [Child Welfare Act, Finland, 417/2007.]

Malloch, M., \& Burgess, C. (2011). Responding to young runaways: Problems of risk and responsibility. Youth Justice, 11(1), 61-76. http://dx.doi.org/10.1177/1473225410394281

Myllärniemi, A. (2006). Huostaanottojen kriteerit pääkaupunkiseudulla. Selvitys pääkaupunkiseudun lastensuojelun sijoituksista [The criteria for taking into care in the 
capital region]. SOCCA:n ja Heikki Waris instituutin julkaisusarja 7. Helsinki, Finland: SOCCA and Heikki Waris instituutti.

Pekkarinen, E. (2010). Stadilaispojat, rikokset ja lastensuojelu. Viisi tapaustutkimusta kuudelta vuosikymmeneltä [Stadi-boys, crime and child protection: Five case studies from six decades]. Helsinki, Finland: Nuorisotutkimusverkosto and Nuorisotutkimusseura, Julkaisuja 102.

Pekkarinen, E. (2011). Lastensuojelun tieto ja tutkimus - Asiantuntijoiden näkökulma [Knowledge and research in child protection - The expert's point of view]. Helsinki, Finland: Nuorisotutkimusverkosto and Nuorisotutkimusseura, Verkkojulkaisuja 51.

Pösö, T., Kitinoja, M., \& Kekoni, T. (2010). Locking up for the best interests of the child - some preliminary remarks on 'special care’. Youth Justice, 10(3), 245-257. http://dx.doi.org/10.117

Pösö, T., \& Laakso, R. (2014). Matching children and substitute homes: some theoretical and empirical notions. Child \& Family Social Work (Early View online version). doi: $\underline{10.1111 / \text { cfs. } 12144}$

Saari, E. (1965). Karkailun ongelma [The problem of runaways]. Pieksämäki, Finland: Sisälähetysseuran Raamattutalon kirjapaino.

Satka, M., Harrikari, T., Hoikkala, S., \& Pekkarinen, E. (2007). The diverse impacts of the neoliberal social policies on children's welfare and social work with young people: The Finnish perspective. Social Work and Society, 5(3), 125-135.

Vehkalahti, K. \& Hoikkala, S. (2013). Gender and discipline in the Finnish reformatories of the 1920s. Journal of the History of Childhood and Youth, 6(3), 457-481. http://dx.doi.org/10.1353/hcy.2013.0044 


\section{Endnotes}

${ }^{1}$ The study was carried out by two external researchers, social workers Ms. Irma Lehtonen (M.Soc.Sc.) and Mr. Janne Telén (M.Soc.Sc.). It was funded by the Alli Paasikivi Foundation and supervised by a multiprofessional advisory group. The writers of this article are Senior Advisors at CUCW and they have been involved with the research process as advisory group members. CUCW has the copyright for the research data and materials.

2 The following partners participated in the preparation process: CUCW; the Association of Finnish Local and Regional Authorities; the Family Federation of Finland; the National Institute for Health and Welfare; the cities of Helsinki, Espoo, and Vantaa; and three service providers.

${ }^{3}$ This study excluded both children placed without a care order and children placed into foster care.

${ }^{4}$ In Saari’s book, "absconding case” means a situation when one person had run away once; "absconding trip" refers to a case when there was an absconding situation including one or more absconders, and the absconder was a person who had absconded one or more times from "his dwelling-place” (1965, p. 43).

${ }^{5}$ By tropism, Erkki Saari refers to a child’s propensity to run away.

${ }^{6}$ Most managers had a qualification at least from a university of applied sciences in a program related either to social or health matters. Most caregivers also had a degree from a similar program. However, $2.4 \%(n=33)$ of all workers $(n=1389.5)$ had no appropriate educational background (CUCW, 2013, p. 16).

${ }^{7}$ Residential care units receiving the questionnaire included private children's homes, the six reform schools run by the state, and the reception centres and children's homes of the twenty biggest municipalities or joint municipalities, as well as private reception centres.

${ }^{8}$ The number of responses was low, 19.6\% out of total. Reasons for this low number can only be speculated on. However, researchers were contacted and feedback was given concerning the questionnaire itself. According to some, the questionnaire was considered too difficult and timeconsuming to fill in. 